\title{
THE INFLUENCE OF QUALITY OF WORK LIFE, WORK FACILITIES, AND ORGANIZATIONAL COMMITMENT ON JOB SATISFACTION
}

\author{
Ida Ayu Iswari Pidada ${ }^{a}$ \\ Ni Putu Rikaandriani ${ }^{\text {b }}$
}

Fakultas Ekonomi Dan Bisnis, Universitas Pendidikan Nasional, Denpasar

Email: iaiswaripdd@gmail.com ${ }^{\mathrm{a}}$; andrianirika15@gmail.com ${ }^{\mathrm{b}}$

ARTICLE HISTORY

Received:

12 December 2020

Revised

15 April 2021

Accepted:

27 May 2021

Online available:

20 November 2021

Keywords:

Quality of work life, Work Facilities, Organizational

Commitment, Job

Satisfaction.

\begin{abstract}
Introduction: This study aims to analyze the influence of quality of work life, work facilities, and organizational commitment on job satisfaction at the Karma Royal Jimbaran hotel.

Methods: The population in this study are employees of Karma Royal Jimbaran with a total sample of 30 people. Data collection techniques in this study are using documentation, interviews, observations, and questionnaires. The data analysis technique uses multiple linear regression analysis.

Results: The results shows that quality of work life, work facilities and organizational commitment have positive and significant effect on employee job satisfaction at Hotel Karma Royal Jimbaran.

Conclusion and suggestion: For Hotel Karma Royal Jimbaran, the results of this study can be used as a theoretical basis to increase employee job satisfaction by increasing the quality of work life which is implemented by paying attention to the welfare of employees through the salaries received by employees, improving work facilities which are implemented by optimizing the availability of transportation for employees. thus supporting the speed and timeliness of employees' work also increasing organizational commitment to employees, this is implemented by building a conducive work environment and giving employees proper rights so that it will increase employee loyalty and employee commitment to continue working at the Karma Royal Jimbaran Hotel.
\end{abstract}

\section{INTRODUCTION}

Facing the current COVID-19 pandemic conditions, companies in the hospitality sector are certainly experiencing a huge impact, because of the limited number of tourist visits has caused many hotels to experience a very significant decline in room 
sales. Karma Royal Jimbaran is one of the four (4) star hotels in Bali that is affected by Covid-19, as a result number of employees has to be laid off. This of course has an impact on employee job satisfaction. Based on the results of interviews, it is found that the hotel room occupancy rate has decreased by almost $90 \%$ since the pandemic, this causes employees financial compensation can not be provided. As a result, employee satisfaction has decreased due to salaries that cannot be issued by the hotel. Even before the pandemic, guest visits at Karma Royal Jimbaran had fluctuated. Based on the results of observations on the number of guest visits at Karma Royal Jimbaran in 2019, it was recorded that from January to December, respectively, there were 297, 213, 338, 243, 298, 1320, 1239, 1334, 1032, 769, 653, and 994 people. Based on these data, it can be seen that there is a fluctuation in the number of guests visiting Karma Royal Jimbaran, the fluctuating data tends to show a significant decrease. In addition, data on guest visits from Karma Royal Jimbaran from 2015 to 2019 also showed fluctuations, this indicates that the increase or decrease in guest visits is not solely caused by the COVID-19 pandemic, but also due to other factors originating from the hotel management and hotel employees. As a hotel with a 4-star category, the Karma Royal Jimbaran hotel must have facilities and services that are in accordance with 4-star hotel standards, besides that employees must also have awareness of the hotel category and work in accordance with Standard Operating Procedures (SOPs) for 4-star hotels, so that the hotel has an image both in the eyes of hotel visitors and also able to maintain competition with other hotels. The following is data on guest visits in the last 5 years obtained from the hotel management.

Table 1

Number of Visits of Karma Royal Jimbaran Guests in 2015-2019

\begin{tabular}{cccccc}
\hline & \multicolumn{5}{c}{ Visitor } \\
\hline January & 2015 & 2016 & 2017 & 2018 & 2019 \\
\hline February & 896 & 987 & 634 & 301 & 297 \\
March & 1012 & 1098 & 798 & 336 & 213 \\
April & 976 & 1102 & 775 & 411 & 338 \\
May & 998 & 901 & 780 & 263 & 243 \\
June & 941 & 990 & 907 & 432 & 298 \\
July & 933 & 1210 & 933 & 1278 & 1320 \\
August & 1152 & 1012 & 996 & 1265 & 1239 \\
September & 1082 & 1250 & 843 & 1457 & 1334 \\
Oktober & 996 & 1189 & 743 & 1428 & 1032 \\
November & 943 & 1300 & 874 & 865 & 769 \\
Desember & 923 & 1347 & 924 & 876 & 653 \\
\hline Total & 1134 & 1134 & 912 & 1085 & 994 \\
\hline Source: Karma Royas & 11.986 & 13.520 & 10.119 & 9.997 & 8.730 \\
\hline
\end{tabular}

Source: Karma Royal Jimbaran, 2020 
Referring to the data table, it is found that there is a significant decrease in the number of guest visits, this is certainly an interesting phenomenon to study in order to find out what caused the decrease in guest visits. It is indicated that the decrease in visits is a result of declining hotel services because of the employee's performance does not seem optimal. Observation results show that the decline in the quality of employee work is caused by a high employee turnover rate, so that in 2019 the number of employees is minimal and causes employee performance to be not optimal. The following is employee turnover data.

Table 2

Karma Royal Jimbaran Employee Turnover 2015-2019

\begin{tabular}{c|c|c|c}
\hline Year & New Employees & Employees leave & Total Employees \\
\hline 2014 & - & - & 54 \\
2015 & 15 & 2 & 67 \\
2016 & 11 & 7 & 63 \\
2017 & 0 & 16 & 47 \\
2018 & 3 & 7 & 43 \\
2019 & 2 & 15 & 30 \\
\hline
\end{tabular}

Sumber: Karma Royal Jimbaran, 2020

Referring to the data table, it is found that employee turnover is quite high, which causes hotel operations to experience disruption. Most of the employee turnover occurred in 2017 due to sluggish tourism, besides that there were indeed some internal problems with employees. In addition, based on the results of interviews with HRD Karma Royal Jimbaran, data is obtained that busy activities due to various activities causing employees to have to take more than one position, so that some are concurrently staff, plus a monthly sales target of 500 million rupiah, with a total of 30 employees and concurrent work status make employees accustomed to the complexity of the task and the dense work atmosphere. The 15 rooms with occupancy on average 90 percent before the pandemic are also one of the factors for the dense activity of the hotel.

Job satisfaction can be affected by several factors, namely the quality of work life. Shanti and Mujiati (2016) stated that the quality of work life is an effort carried out by a management to the level of an employee's quality by rewarding and paying attention to all factors on his/her working conditions, in order to create harmony between a worker and other factors that have influence on his/her work. Accustomed to dealing with crowded situations with high work routines employees experience unusual conditions when a pandemic arises, because some activities are lost and employees feel bored. This makes the quality of work life in an employee decreases because an employee no longer feels the usual work activities. 
Furthermore, work facilities also affect employee job satisfaction. According to Prasetio (2020) work facilities are facilities and infrastructure that are carried out in helping an employee to facilitate the completion of his/her work so he/she is able to provide an increasement to his/her performance. Based on interviews conducted, one of the example of employee dissatisfaction at work facilities is an employee room that has less open air circulation, causing employees to feel less comfortable. However, after the new normal is implemented, hotel activities began to move, even though only accept a few and domestic tourists. This makes some employee activities carried out by requiring to health protocols so that in line with the current 4.0 era development, running a hotel can be done from anywhere, from booking hotels which can be done through digital applications so as to minimize meetings.

Furthermore, organizational commitment is a factor that affects employee job satisfaction. Organizational commitment is an attitude that shows a loyal attitude to an organization and a continuous process in which its members are able to predict a concern to the organization and its success as well as its continuous progress (Hariani et al., 2019). Referring to the interview results, it is found that the average arrival time of Karma Royal Jimbaran employees is above 07.30 WITA, whereas for the morning shift employee arrivals should not be more than 07.30 WITA, even the average range was at 08.00 WITA. Being late for work even up to thirty minutes is an indication that the employee's work commitment is still not optimal.

In addition to the inaccuracy of time, the employee absentee level of Karma Royal Jimbaran is quite high, this is obtained from the results of an observation. Referring the observation, it can be seen that the increase in employee absentee at Karma Royal Jimbaran is above three percent, namely $6.63 \%$. Absence rates above three percent already indicate a problem in employee performance. So that the employee absentee level of Karma Royal Jimbaran is high, so it is indicated that the employee's organizational commitment is still not maximized if considering the number of employees are not many, only 30 people. Therefore, if there are employees who are absent it will greatly affect the work structure and the productivity of the hotel.

\section{LITERATURE REVIEW}

\section{Quality of work life}

Shanti and Mujiati (2016) stated that the quality of work life is an effort carried out by a management to the level of an employee's quality by rewarding and paying attention to all factors in his/her working conditions, in order to create harmony between a worker and other factors that have an influence on his/her work. Accustomed to dealing with crowded situations with high work routines employees experience 
unusual conditions when a pandemic arises, because some activities are lost and employees feel bored. This makes the quality of work life in an employee decreases because an employee no longer feels the usual work activities.

\section{Work Facilities}

According to Prasetio (2020) work facilities are facilities and infrastructure that are carried out in helping an employee to facilitate the completion of his/her work so that he/she is able to provide an attachment to his/her performance.

\section{Organizational Commitment}

Organizational commitment is an attitude that shows a loyal attitude to an organization and a continuous process in which its members are able to predict a concern for the organization and its success as well as its continuous progress (Hariani et al., 2019).

\section{Job Satisfaction}

Job satisfaction is an emotional state of how employees assess their work and interact with their work environment (Hariani, Irfan and Souisa, 2019). Job satisfaction is a feeling that is able to give a sense of satisfaction to the work carried out by an employee, so that the employee will feel happy and satisfied in doing his/her job.

\section{RESEARCH METHODS}

This research is conducted at Karma Royal Jimbaran which is located in Jimbaran, Badung, Bali. The selection of this location is due to on phenomena that arise based on the results of observations and interviews regarding the not yet maximal of employee performance so that there is a decrease in hotel guest visits. The population in this study are employees of Karma Royal Jimbaran with a total sample of 30 people. Data collection techniques are documentation, interviews, observations, and questionnaires. The data analysis technique uses multiple linear regression analysis with the following equation:

$$
Y=\alpha+\beta 1 X 1+\beta 2 X 2+\beta 3 X 3+\epsilon
$$

Description:

$$
\begin{aligned}
& \mathrm{Y} \quad=\text { Job Satisfaction } \\
& \alpha=\text { Constant } \\
& \beta=\text { Line Coeffecient } \\
& \text { regresi } \epsilon=\text { error } \\
& \text { (X1) = Quality of Work Life } \\
& \text { (X2) = Work Facility } \\
& \text { (X3) = Organizational Commitment }
\end{aligned}
$$




\section{RESULT AND ANALYSIS}

Referring to the results of the study, it is found that the respondents aged $<20$ years are 5 people with a percentage of $16.7 \%$. Respondents aged $20-30$ are 20 people with a percentage of $66.7 \%$. Respondents aged $30-40$ years are 5 people with a percentage of $16.7 \%$. This shows that respondents aged $20-30$ years are the most dominating. Referring to the results of the study, the respondents with male sex are 17 people with a percentage of $56.7 \%$. Respondents with female sex as many as 13 people with a percentage of $43.3 \%$. This shows that male respondents are the most dominant.

Referring to the results of the study, the respondents with a working period of 1-5 years are 10 people with a percentage of $33.3 \%$. Respondents with a working period of $5-10$ years are 17 people with a percentage of $56.7 \%$, and respondents with a working period of $>10$ years are 3 people with a percentage of $10.0 \%$. This shows that respondents with a working period of $5-10$ years dominate.

Referring to the results of the study, the respondents with the latest high school education are 17 people with a percentage of $56.7 \%$. Respondents with the latest education Diploma as many as 8 people with a percentage of $26.7 \%$ and respondents with the latest education Bachelor as many as 5 people with a percentage of $16.7 \%$. This shows that respondents with the last education of high school dominate.

\section{Table 3}

\section{Multiple Regression Test}

Coefficients $^{\mathbf{a}}$

\begin{tabular}{|c|c|c|c|c|c|}
\hline \multirow[b]{2}{*}{ Model } & \multicolumn{2}{|c|}{$\begin{array}{c}\text { Unstandardized } \\
\text { Coefficients }\end{array}$} & \multirow{2}{*}{$\begin{array}{l}\text { Standardized } \\
\text { Coefficients } \\
\text { Beta }\end{array}$} & \multirow[b]{2}{*}{$\mathrm{T}$} & \multirow[b]{2}{*}{ Sig. } \\
\hline & B & Std. Error & & & \\
\hline 1 (Constant) & $-1,693$ & 2,300 & & $-0,736$ & 0,468 \\
\hline Quality Of Work Life & 0,170 & 0,063 & 0,296 & 2,695 & 0,012 \\
\hline Work Facilities & 0,302 & 0,095 & 0,457 & 3,190 & 0,004 \\
\hline $\begin{array}{l}\text { Organizational } \\
\text { Commitment }\end{array}$ & 0,231 & 0,094 & 0,303 & 2,465 & 0,021 \\
\hline $\mathrm{R}$ & 0,893 & & & & \\
\hline R Square & 0,798 & & & & \\
\hline Adjusted R Square & 0,775 & & & & \\
\hline F count & 34,217 & & & & \\
\hline Sig. & 0,000 & & & & \\
\hline
\end{tabular}

Source: Primary Data Processed, 2020 (Attachment 8)

Based onto the table that the equation is as follows:

$$
Y=-1,693+0,170 X 1+0,302 \times 2+0,231 X 3
$$


Table 4

Simultaneous Test (F Test)

ANOVA $^{a}$

\begin{tabular}{llrrrrc}
\hline \multirow{2}{*}{ Model } & \multicolumn{2}{c}{$\begin{array}{c}\text { Sum of } \\
\text { Squares }\end{array}$} & Df & Mean Square & $F$ & Sig. \\
\hline 1 & Regression & 110,669 & 3 & 36,890 & 34,217 & $0,000^{\mathrm{b}}$ \\
\cline { 2 - 7 } & Residual & 28,031 & 26 & 1,078 & & \\
\cline { 2 - 7 } & Total & 138,700 & 29 & & & \\
\multicolumn{5}{l}{ Source: Primary Data Processed, 2020 (Attachment 10) }
\end{tabular}

Based onto the ANOVA test table that the F value is 34.217 with a sig. of $0.000<0.05$, meaning that the quality of work life, work facilities and organizational commitment simultaneously have an influence on job satisfaction at the Karma Royal Jimbaran Hotel.

Table 5

Beta Coefficient Test Results

\begin{tabular}{clcc} 
No & \multicolumn{1}{c}{ Variable } & Beta Coeffecient & Order \\
\hline 1 & Quality Of Work Life & 0,170 & 3 \\
\hline 2 & Work Facilities & 0,302 & 1 \\
\hline 3 & $\begin{array}{l}\text { Organizational } \\
\text { Commitment }\end{array}$ & 0,231 & 2
\end{tabular}

Source: Processed Data, 2020 (Attachment 10)

Based on the table above, it is known that the beta coefficient value of the work facilities variable has the largest value, which is 0.302 compared to the beta coefficient value of the quality of work life and organizational commitment variables. So it can be concluded that the influence of work facilities dominates job satisfaction at Hotel Karma Royal Jimbaran, higher than the variables of quality of work life and organizational commitment.

\section{The Influence of Quality of Work Life on Job Satisfaction}

Referring to the t-test, the quality of work life on job satisfaction is obtained by seeing t-count value $>$ t-table $(2.695>1.706)$ and the significance value is $0.012<0.05$ with the regression coefficient value 0.170 having a positive value, so it is concluded as acceptance of $\mathrm{H} 1$. Meaning that the quality of work life variable has a positive influence on job satisfaction at the Karma Royal Jimbaran Hotel. Shanti and Mujiati (2016) stated that the quality of work life is an effort carried out by a management to the level of an employee's quality by rewarding and paying attention to all factors in his/her working conditions, in order to create harmony between a worker and other factors that have an influence on his/her work. Accustomed to dealing with crowded situations with high work routines employees experience unusual conditions when a pandemic arises, because some activities are lost and employees feel bored. This makes the quality of work life in an employee decreases because an employee no longer feels the usual work activities. 
The results of this study are in line with research conducted by Setiyadi and Wartini (2016) which stated that the variable quality of work life has a positive effect on job satisfaction.

\section{The Influence of Job Facilities on Job Satisfaction}

Referring to the t-test that the influence of work facilities on job satisfaction is obtained by seeing t-count value $>$ t-table $(3.190>1.706)$ and the significance value of $0.004<0.05$ with a regression coefficient value of 0.302 . It can be said that work facilities has a positive value, meaning the acceptance of $\mathrm{H} 1$. The results can be concluded that the work facilities variable has a positive influence on job satisfaction at the Karma Royal Jimbaran Hotel.

According to Prasetio (2020) work facilities are facilities and infrastructure that are carried out in helping an employee to facilitate the completion of his/her work so he/she is able to provide an increasement to his/her performance. Based on interviews conducted, one of the example of employee dissatisfaction at work facilities is an employee room that has less open air circulation, causing employees to feel less comfortable. However, after the new normal is implemented, hotel activities began to move, even though only accept a few and domestic tourists. This makes some employee activities carried out by requiring to health protocols so that in line with the current 4.0 era development, running a hotel can be done from anywhere, from booking hotels which can be done through digital applications so as to minimize meetings.

The results of this study are in line with research conducted by Angin (2020) which stated that the work facility variable has a positive effect on employee job satisfaction.

\section{The Influence of Organizational Commitment on Job Satisfaction}

Referring to the t-test, the organizational commitment to job satisfaction obtained the t-count value $>$ t-table $(2.465>1.706)$ and the significance value is 0.021 $<0.05$ with the regression coefficient value 0.231 having a positive value so means the acceptance of $\mathrm{H} 1$. Meaning that the organizational commitment variable has a positive influence on job satisfaction at the Karma Royal Jimbaran Hotel.

Organizational commitment is an attitude that shows a loyal attitude to an organization and a continuous process in which its members are able to predict a concern for the organization and its success as well as its continuous progress (Hariani et al., 2019).

The results of this study are in line with research conducted by Angin (2017) which showed that the variable organizational commitment has a positive influence on job satisfaction. 


\section{CONCLUSION}

The results shows that quality of work life, work facilities and organizational commitment have a positive and significant positive effect on employee job satisfaction at Hotel Karma Royal Jimbaran.

For Hotel Karma Royal Jimbaran, the results of this study can be used as a theoretical basis to increase employee job satisfaction by increasing the quality of work life which is implemented by paying attention to the welfare of employees through the salaries received by employees, improving work facilities which are implemented by optimizing the availability of transportation for employees. thus supporting the speed and timeliness of employees work also increasing organizational commitment to employees, this is implemented by building a conducive work environment and giving employees proper rights so that it will increase employee loyalty and employee commitment to continue working at the Karma Royal Jimbaran Hotel.

\section{REFERENCES}

Anam, K., \& Rahardja, E. (2017). Pengaruh Fasilitas Kerja, Lingkungan Kerja Non Fisik dan Kepuasan Kerja Terhadap Kinerja Karyawan (Studi pada Pegawai Dinas Perindustrian dan Perdagangan Provinsi Jawa Tengah). Diponegoro Journal of Management, 6(4), 502-512.

Ghozali, Imam. (2016). Aplikasi Analisis Multivariate dengan Program IBM SPSS21 Update PLS Regresi. Semarang: Badan Penerbit Universitas Diponogoro.

Hariani, M., Irfan, M., \& Souisa, F. N. (2019). Pengaruh Penilaian Kinerja Dan Komitmen Organisasi Terhadap Kepuasan Kerja Penyuluh Pertanian. Ekonomi, Keuangan, Investasi Dan Syariah (EKUITAS), 1(1), 30-36.

Parangin-Angin, S. U. (2020). Pengaruh Fasilitas Kerja Dan Karakteristik Pekerjaan Terhadap Kepuasan Kerja Dalam Upaya Meningkatkan Kinerja Pegawai Di Kantor Pelayanan Pajak Pratama Tebing Tinggl. JRAM (Jurnal Riset Akuntansi Multiparadigma), 7(1), 1-14.

Santhi, N. P. M. C., \& Mujiati, N. W. (2016). Pengaruh Quality Of Work Life, dan Motivasi terhadap Kepuasan Kerja Karyawan. E-Jurnal Manajemen Universitas Udayana, 5(11).

Setiyadi, Y. W., Wartini, S., \& Wijayanto, A. (2016). Pengaruh Kualitas Kehidupan Kerja Terhadap kinerja karyawan dengan kepuasan kerja sebagai variabel intervening. Management Analysis Journal, 5(4). 
Sulaimawan, D. (2020). Analisis Pengaruh Budaya Organisasi Dan Fasilitas Kerja Terhadap Kepuasan Kerja Berdampak Pada Kinerja Pegawai. Commerce Jurnal IImiah, 8(1).

Suliyanto. (2018). Metode Penelitian Bisnis. Andi Offset: Yogyakarta.

Utama, I.B.R. (2018). Statistik Penelitian Bisnis dan Pariwisata. Andi Offset: Yogyakarta. 